
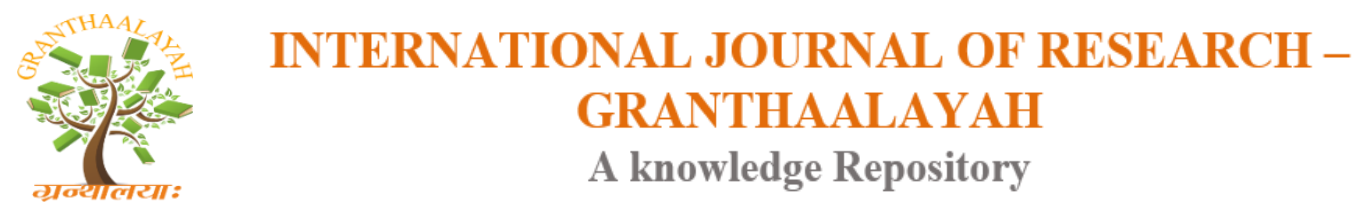

Science

\title{
DEVELOPMENT OF VALUE ADDED PRODUCT FROM FINGER MILLET (Eleusine coracana)
}

\author{
Vaishnavi Devi.N ${ }^{1}$, R.Sinthiya ${ }^{2}$ \\ ${ }^{1}$ Scholar, Faculty of Engineering, Avinashilingam Institute for Home Science and Higher \\ Education for Women, Coimbatore-641108, India \\ ${ }^{2}$ Assistant Professor Department of Food Processing and Preservation Technology, \\ Avinashilingam Institute for Home Science and Higher Education for Women, Coimbatore- \\ 641108, India
}

\begin{abstract}
The value-added millet-based chips are basically prepared by using the ingredient ragi (finger millet). Ragichips are highly comprised of amino acids, minerals like calcium, iron and carbohydrates. It is low in fat and most of which are unsaturated fats. The chips are organoleptically evaluated and tested in laboratory with basic variations of flours. This chip is found to be affected after a minimum storage of 15 days without any increase in moisture content.
\end{abstract}

Keywords: Ragi Chips; Bengal Gram Flour; Rice Flour; Health Benefits.

Cite This Article: Vaishnavi Devi.N, and R. Sinthiya. (2018). "DEVELOPMENT OF VALUE ADDED PRODUCT FROM FINGER MILLET (Eleusine coracana)." International Journal of Research - Granthaalayah, 6(2), 109-119. https://doi.org/10.5281/zenodo.1186584.

\section{Introduction}

Millets are a group of highly variable small- seeded grasses widely grown around the world as cereal crops or grains for fodder and human food. Millets are important crops in the semi arid tropics of Asia and Africa (especially in India, Mali, Nigeria, Niger) with $99 \%$ of millet production in developing countries. The crop is flavored due to its productivity and short growing season under dry, high temperature conditions. There is variety of millets available in India such as foxtail millet (kangni), sorghum millet (bajra), little millet (kutki), kodo millet (kodra) and pearl millet (Jowar). Ragi is commonly known as finger millet in southern part of India. Along with any other food this is one of the most nutritious food and one which is easy to digest. It is rich in calcium and protein and also has good amount of iron and other minerals. It has least amount of fat and rich in carbohydrates of around $80 \%$. Ragi has high amount of calcium, is one of the important ingredients of our body and our daily need is around $350 \mathrm{mg}$.There are traces of iron and rest of other minerals are very small. 


\subsection{Nutritional Facts}

Finger millet is considered one of the most nutritious cereals. Finger millet contains about 5-8\% protein, 1-2\% ether extractives, 65-75\% carbohydrates, 15-20\% dietary fiber and $2.5-3.5 \%$ minerals. Of all the cereals and millets, finger millet has the highest amount of calcium (344 $\mathrm{mg} \%$ ) and potassium (408mg\%). The cereal has low fat content (1.3\%) and contains mainly unsaturated fat. 100 grams of Finger millet has roughly on an average of $336 \mathrm{KCal}$ of energy in them.

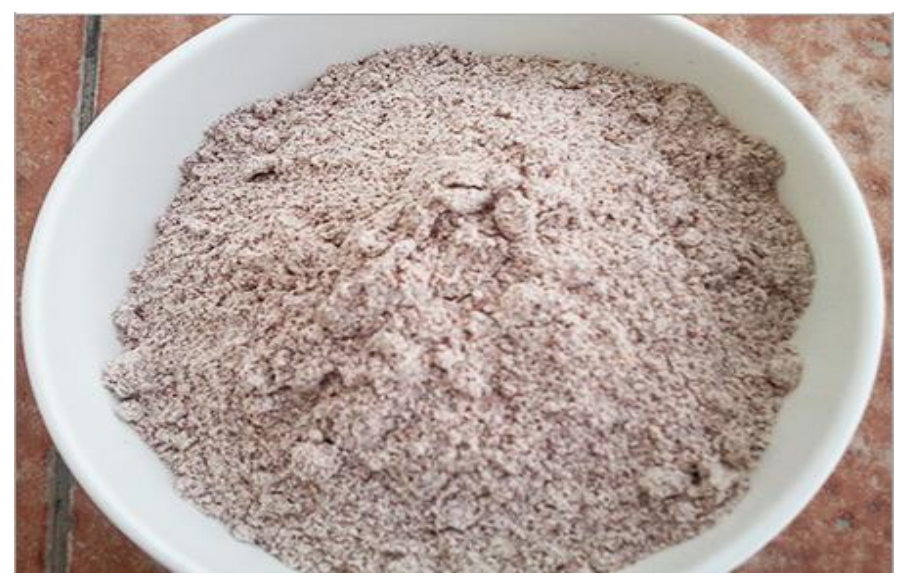

Figure 1: Ragi flour

However, the millet also contains phytates $(0.48 \%)$, polyphenols, tannins $(0.61 \%)$, trypsin inhibitory factors, and dietary fiber, which were once considered as "anti nutrients" due to their metal chelating and enzyme inhibition activities (Thompson 1993) but nowadays they are termed as neutraceuticals. Being non-glutinous, finger millet is safe for people suffering from gluten allergy and celiac disease. It is non-acid forming, and hence easy to digest. Finger millet is rich in amino acids (Tryptophan, Threonine, Valine, Isoleucine and Methionoine).

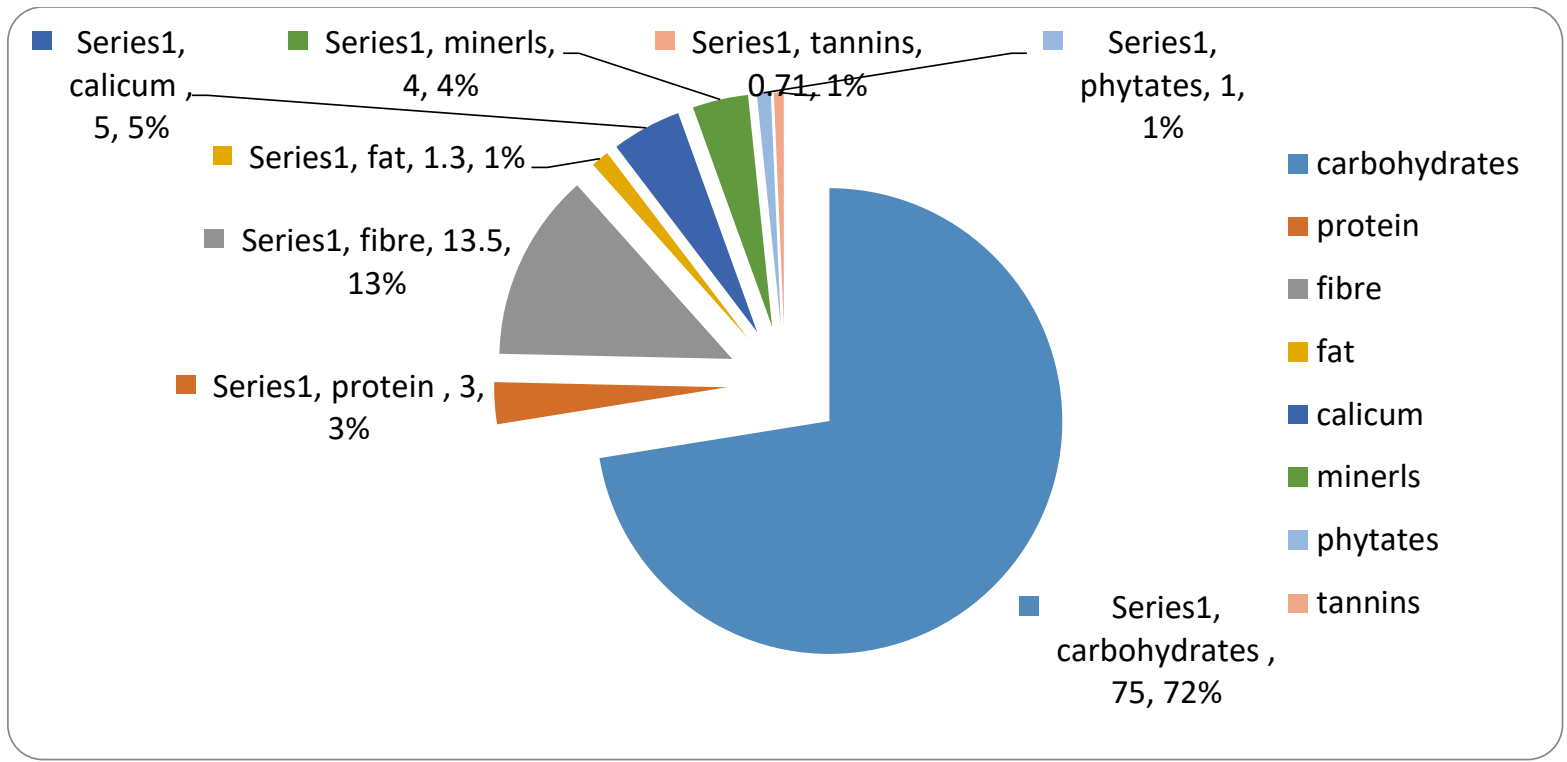

Figure 2: Nutritive value of ragi flour 


\subsection{Amino Acids}

Ragi also has some good number of Essential Amino Acids (EAA) which are essential for human body. Few of the key EAAs which Ragi has are Valine, Methionine, Isoleucine, Threonine and Tryptophan.Below section (figure.3) briefly explains why these are essential for us:

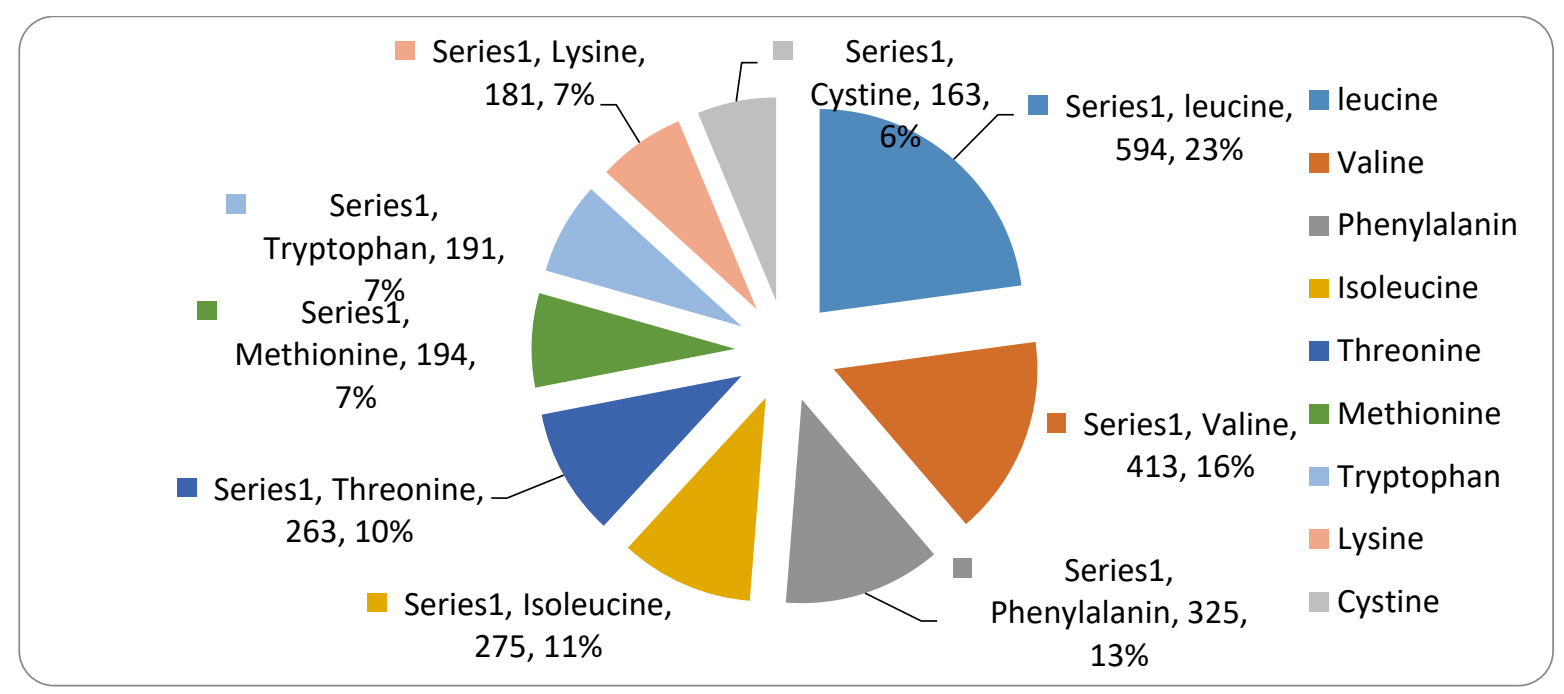

Figure 3: Amino acids in Ragi flour

- Valines are essential for repair of tissues, muscle coordination and metabolism and also help maintain balance of nitrogen in the body. It also help promote mental calmness and enhance maintain mental vigor.

- Isoleucine is essential for ensuring blood formation, keeping a check on blood sugar levels. It also helps heal and repair muscle tissues, bones and skin.

- Threonine helps maintain protein levels in the body. It also helps formation of tooth enamel, also prevents formation of fat in the liver.

- Tryptophan which act as natural relaxant and help fight anxiety, depression and insomnia. They also help in treating migraine headaches. They reduce excess appetite and help control weight gain; they also release of growth harmones.

- Methionoine which is a sulfur based amino acid which is essential for various activities in human body. It is said to help promote growth of healthy skin and called lecithin which helps reduce cholesterol, reduce fat inside the livers and help protect kidneys. This methionine is generally lacking in staple diet of some of the vegetarians and hence regular Ragi intake will help get enough of these amino acids.

\subsection{Health Benefits of Ragi Flour}

\subsubsection{Loaded with Calcium}

Ragi is one of the best non-dairy sources of calcium when compared to any other grains. According to the National Institute of Nutrition in India, 100 grams of Ragi contains $344 \mathrm{mg}$ calcium. It is critical for healthy bones and teeth and prevention of osteoporosis - a disease which 
weakens the bones. It is extremely beneficial for growing kids and can be given in the form of Ragi Porridge.

\subsubsection{Helps in Controlling Diabetes}

The grain's seed coat is abundant in polyphenols and dietary fibres as compared to rice, maize or wheat. The low glycemic index lessens food cravings and maintains the digestive pace, consequently, keeping blood sugar within the safe range. It is best to add it to your morning meal or have it for lunch in order to keep your system on track the whole day.

\subsubsection{Reverts Skin Ageing}

Ragi works wonders for maintaining young and youthful skin. Vital amino acids like Methionine and Lysine present in it make the skin tissues less prone to wrinkles and sagging. Ragi is also one of the very few natural sources of Vitamin D which is mostly derived from sunlight. Vitamin $\mathrm{D}$ is a carrier molecule for calcium, which accounts for vitality.

\subsubsection{Battles Anemia}

Ragi is an excellent source of natural iron and thus a boon for anemic patients and also for those with low haemoglobin levels. Once ragi is allowed to sprout, the Vitamin $\mathrm{C}$ levels tend to increase and lead to easy absorption of iron into the bloodstream. For the optimum absorption of iron, you can consume it in the form of ragi balls, ragi chips, ragidhosa with plenty of vegetables.

\subsubsection{Relaxes the Body}

Regular consumption of Ragi is highly beneficial in dealing with conditions of anxiety, depression and insomnia. The presence of antioxidants, mainly Tryptophan and amino acids, helps as they work as natural relaxants. Ragi consumption is also useful for migraines.

\subsubsection{Helps in Weight Loss}

The high amount of dietary fiber combine keeps the stomach full for a longer and prevents unwanted cravings. This in turn leads to a minimized appetite and weight loss. Ragi lowers your blood sugar levels in the body by activating insulin.

\section{Materials and Methods}

The primary ingredients used in the preparation of Ragi (finger millet) chips include finger millet (ragi) flour, Urad dhal flour and rice flour. The secondary ghee, red chillies, curry leaves, garlic, salt, water and oil for frying.

\subsection{Rice Flour}

Rice flour (also rice powder in figure 4) is a form of flour made from finely milled rice. It is distinct from rice starch, which is usually produced by steeping rice in lye. Rice flour is a 
particularly good substitute for wheat flour, which some people believe irritates their digestive system. Rice flour is also used as a thickening agent in recipes that are refrigerated or frozen since it inhibits liquid separation. Rice flour may be made from either white rice or brown rice. To make the flour, the husk of rice or paddy is removed and raw rice is obtained, which is then ground to flour.

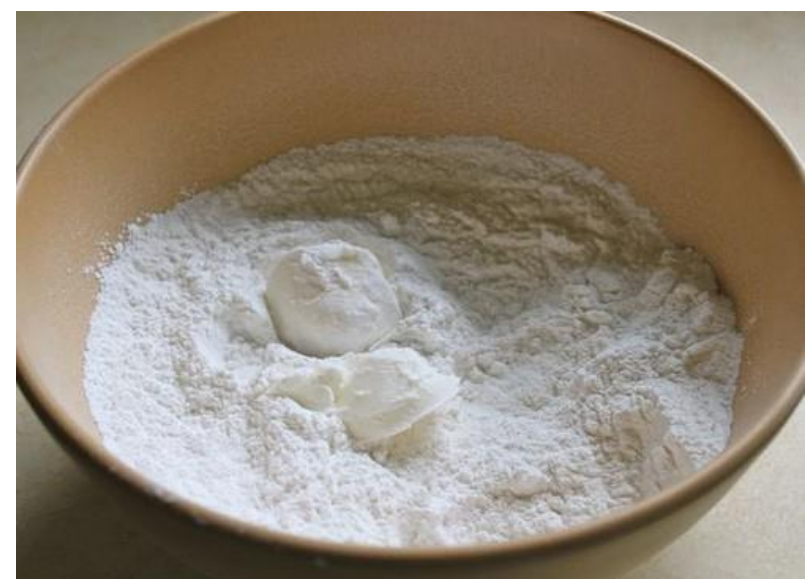

Figure 4: Rice flour (Powdered rice)

\subsection{Black Gram Flour}

Black gram, urad bean, minapapappu, mungo bean is a bean grown in the Indian subcontinent. At one time it was considered to belong to the same species as the mung bean. The product sold as black lentil is usually the whole urad bean, whereas the split bean (the interior being white) is called white lentil. It should not to be confused with the much smaller true black lentil (Lens culinaris). It is also extensively used in South Indian culinary preparations. Black gram is one of the key ingredients in making the idli-dosa batter, where one part of black gram is mixed with three or four parts of idli rice to make the batter. Also, the dough for vada, chips or udidvada is made from soaked batter and deep fried in cooking oil. The dough is also used in making papadam, in which white lentils are usually used. The figure 5 is given below.

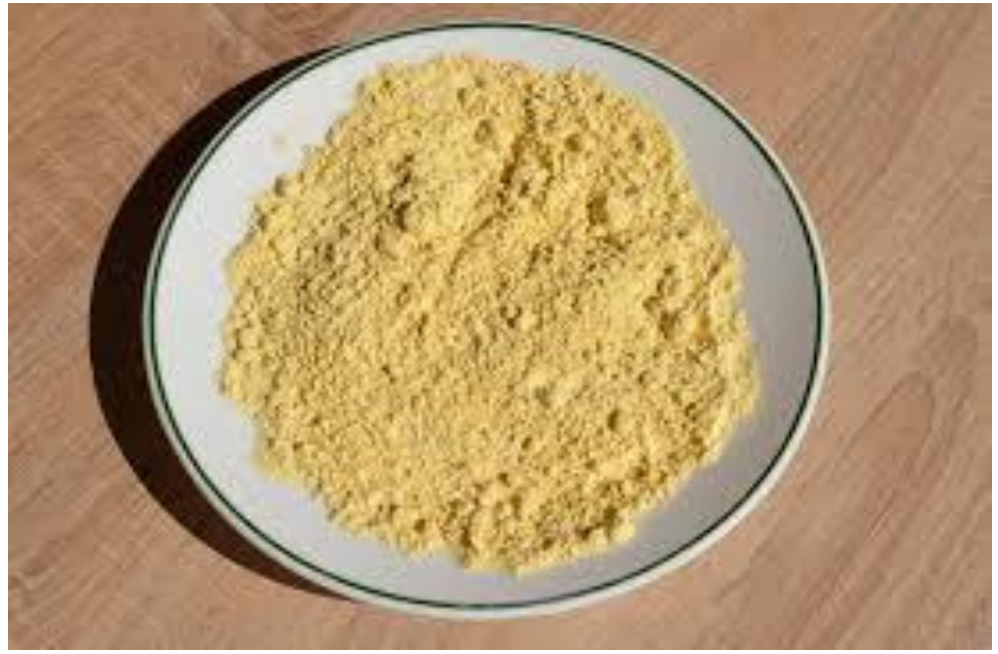

Figure 5: Black gram flour 


\subsection{Preparation of Ragi (Finger Millet) Chips}

Mix all the above-mentioned flours (ragi flour, rice flour, urad dhal flour). Add salt and grinded red chillies, garlic and curry leaves for the flavour and to get spicy taste. Add some ghee and water to make into dough. Divide the dough into small balls and roll it into round sheets. Cut the sheets into different shapes for the attractive appearance and fry in oil. In method, arrange all the shaped layers in oven tray (add aluminium foil sheet in want)and apply oil with brush and preheat oven on 180 degrees for 10 minutes then bake chips on 150 degrees for 20 minutes till crispy and well done. There are different trails have been conducted to get the best products.

\section{Trail 1}

- The ragi flour and rice flour of equal proportion (20 grams) are mixed along with black gram flour of 5 grams, and spices such ginger, red chillies, garlic are incorporated along with the required amount of salt, water and curry leaves.

\section{Trial 2}

- In the second trial the ingredients such as ragi flour is taken in the proportion of 10 grams and rice flour in the ratio of 15 grams along with black gram flour of 5 grams and spices such as ginger, red chillies, garlic and are incorporated along with the required amount of

\section{Trial 3} salt, water and curry leaves.

- In the third trial the ingredients auch as the ragi flour and rice flour are taken in a ratio of 15 grams each and black gram is taken in a proportion of 7 grams along with the spices such as ginger, garlic, red chillies and are incorporated along with the required amount of salt, water and curry leaves. Of all the three trials the first trial is observed to be the best trial with all the essential nutrient components and is composed of good flavour, texture, appearance, crunchy and has a good mouth.

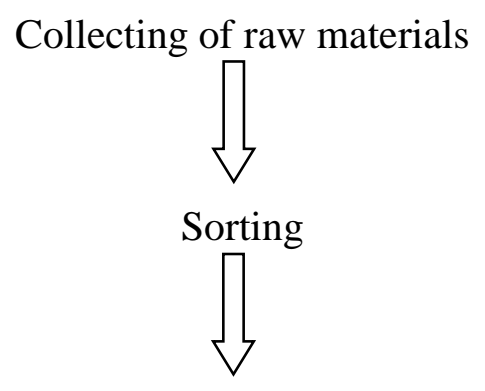

Sieving (removing of foreign materials)

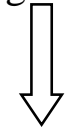

Mixing in uniform proportion<smiles>C=CC=C</smiles>

Addition of secondary ingredients 
Sheeting<smiles>C=CC=C</smiles>

Cutting into uniform size and shape<smiles>C=CC</smiles>

Deep frying<smiles>C=CC=CC</smiles>

Package

Figure 6: Flow process of Finger millet chips

\subsection{Collecting of Raw Materials}

A raw material, also known as a feedstock or most correctly unprocessed material, is a basic material that is used to produce goods, finished products, energy, or intermediate materials which are feedstock for future finished products. The raw used here is primary and secondary raw materials are given in the below table:

Table 1: Ingredients

\begin{tabular}{|l|l|}
\hline Primary ingredients & Secondary ingredients \\
\hline Ragi flour & Red chili flakes \\
\hline Rice flour & Curry leaves \\
\hline Black gram flour & Ginger \\
\hline Water & Garlic \\
\hline Oil & Salt \\
\hline
\end{tabular}

\subsection{Sorting}

Sorting involves in inspection, assessment of various foods regarding quality, freshness, legal conformity and market value. The removal of unwanted or foreign particles in the ingredients is basically known as sorting.

\subsection{Sieving and Grading}

Grading often occurs by hand, in which food s are assessed and sorted. Machinery is also used to grade foods and may involve sorting products by size, shape and quality.

Sieving is simple technique of removing particles of different sizes to get a uniform particle size. There are different types of sieve used in food industries to get a good product. 


\subsection{Mixing}

The mixing is the combination of two or more different materials to get a mass product or a single product. Here these primary and secondary ingredients are mixed thoroughly to form dough.

\subsection{Sheeting and Cutting into Shape}

The dough was made into small balls. These balls are made into thin layer instead of rolling it out with rolling pin, which gives a unique shape. Cutting into uniform shapes and sizes is important for two reasons. It ensures even appearance and texture of the dish.

\subsection{Deep Frying}

Deep frying is a cooking method in which food is submerged in hot fat, most commonly oil, rather than the shallow oil used in conventional frying done in a frying pan. Deep frying foods cook quickly all the sides of a food are cooked simultaneously as oil has a high rate of heat conduction.

\subsection{Storage and Package}

Packaging is the technology of enclosing or protecting products for disturbances, storage, sell and use. Packing contains information about the product in detailed.

\section{Results and Discussions}

\section{Quality Analysis}

Various test and analysis have been done to determine the quality of the product.

- Moisture test

- Ash test

\subsection{Moisture Content}

Moisture content is one of the most commonly measured properties of food materials. It is therefore important for food scientists to be able to reliably measure moisture contents. A number of analytical techniques have been developed for this purpose, which vary in their accuracy, cost, speed, sensitivity, specificity, ease of operation, etc. The choice of an analytical procedure for a particular application depends on the nature of the food being analyzed and the reason the information is needed. The moisture content of a food material is defined through the following equation:

$\%$ Moisture $=\left(m_{\mathrm{w}} / s_{\text {ample }}\right) 100$ Where $m_{\mathrm{w}}$ is the mass of the water and $s_{\text {ample }}$ is the mass of the sample. The mass of water is related to the number of water molecules $\left(n_{\mathrm{ew}}\right)$ by the following expression: $m_{\mathrm{w}}=n_{\mathrm{w}} M_{\mathrm{w}} / N_{\mathrm{A}}$, where $M_{\mathrm{w}}$ is the molecular weight of water (18.0 g per mole) and $N_{\mathrm{A}}$ is Avogadro's number $\left(6.02 * 10^{23}\right.$ molecules per mole). The moisture content is 
determined by measuring the mass of a food before and after the water is removed by evaporation:

$$
\% \text { Moisture }=\frac{M_{\text {IITLLL }}-M_{\text {DRIDD }}}{M_{\text {IRTILL }}} \times 100
$$

Here, $M_{\text {INITIAL }}$ and $M_{\text {DRIED }}$ are the mass of the sample before and after drying, respectively. The basic principle of this technique is that water has a lower boiling point than the other major components within foods, e.g., lipids, proteins, carbohydrates and minerals. Sometimes a related parameter, known as the total solids, is reported as a measure of the moisture content. The total solids content is a measure of the amount of material remaining after all the water has been evaporated.

Thus, $\%$ Total solids $=(100-\%$ Moisture $)$.

$$
\% \text { Total Solids }=\frac{M_{\text {DRILD }}}{M_{\text {DITLLL }}} \times 100
$$

Table 2: Calculation for moisture content in Finger millet chips

\begin{tabular}{|l|l|l|l|l|l|l|}
\hline S.no & Sample & $\begin{array}{l}\text { Initial } \\
\text { weight }(\mathbf{g})\end{array}$ & $\begin{array}{l}\text { Final } \\
\text { weight }(\mathrm{g})\end{array}$ & $\begin{array}{l}\text { Moisture } \\
\text { removed }\end{array}$ & $\begin{array}{l}\text { MC on Wb } \\
(\boldsymbol{\%})\end{array}$ & $\begin{array}{l}\text { MC on db } \\
(\%)\end{array}$ \\
\hline 1. & $\begin{array}{l}\text { Ragi } \\
\text { chips }\end{array}$ & 15 & 12 & 3 & 20 & 30 \\
\hline
\end{tabular}

The 15 grams of instant ragi chips flour is taken in a petri dish, kept in hot air oven for 120 degree for 3 hours. The moisture content in the chips is $20 \%$ on wet basis and on dry basis moisture content is $30 \%$.

\subsection{Ash Content}

Ash or mineral content is the portion of the food or any organic material that remains after it is burned at very high temperature. The ash constituents include potassium, sodium, calcium and magnesium, which are present in larger amounts as well as smaller quantities of aluminium, iron, copper, manganese or zinc, arsenic, iodine, fluorine and other elements present in traces. Ash content represents the total mineral content in foods. Although minerals represent a small proportion of dry matter, often less than $7 \%$ of the total, they play an important role from a physicochemical, technological and nutritional point of view. Determining the ash content may be important for several reasons. It is part of proximate analysis for nutritional evaluation. Ashing is the first step in preparing a food sample for determination of specific elemental analysis.

When powdered foods, are heated to a temperature of about $500^{\circ} \mathrm{C}$ for at least four hours, the water and other volatile constituents are evolved as vapors and the organic constituents are burnt off in the presence of oxygen of the air, to carbon dioxide and oxides of nitrogen and also eliminated together with hydrogen as water. 
Calculations for Ash Test:

Weight of sample before heating

Weight of sample after heating

Weight of total ash (W1-W2)

Total ash content present

$$
\begin{aligned}
& =0.026 \mathrm{~g} \\
& =0.020 \mathrm{~g} \\
& =0.026-0.020 \\
& =0.006 * 100 \\
& =0.6 \%
\end{aligned}
$$

\begin{tabular}{|c|c|c|c|c|c|}
\hline \multirow[t]{2}{*}{ S.No } & \multirow[t]{2}{*}{$\begin{array}{l}\text { Weight of } \\
\operatorname{Sample}(G)\end{array}$} & \multirow[t]{2}{*}{$\begin{array}{c}\text { Weight of } \\
\text { Crucible }(\mathbf{G})\end{array}$} & \multicolumn{2}{|c|}{$\begin{array}{l}\text { Weight of Sample With } \\
\text { Crucible }(G)\end{array}$} & \multirow{2}{*}{$\begin{array}{c}\text { Ash } \\
\text { Content } \\
(\%)\end{array}$} \\
\hline & & & Initial & Final & \\
\hline 1. & 5 & 0.021 & 0.026 & 0.020 & 0.6 \\
\hline
\end{tabular}

Table 3: Calculation for Ash content in the Finger millet chips

The ash test represents the quantity of inorganic residue remains after the incineration of organic matter. The 5 grams of sample is kept at 550 degree in muffle furnace for 3 hours. The ash content in the flour is $0.6 \%$.

Table 3: Sensory Evaluations of Finger Millet Chips

\begin{tabular}{|l|c|c|c|c|}
\hline $\begin{array}{c}\text { People opinion } \\
\text { (excellent, good satisfactory, } \\
\text { unsatisfactory) }\end{array}$ & $\begin{array}{c}\text { Taste } \\
\text { (out of } \\
\mathbf{5}\end{array}$ & $\begin{array}{c}\text { Appearance } \\
\text { (out of 5) }\end{array}$ & $\begin{array}{c}\text { Flavour } \\
\text { (out of } \\
\text { 5) }\end{array}$ & $\begin{array}{c}\text { Rating } \\
\text { (out of } \\
\mathbf{5})\end{array}$ \\
\hline Excellent & 5 & - & 5 & - \\
\hline Very good & - & 4 & - & 4.5 \\
\hline Good & - & - & - & - \\
\hline Satisfactory & - & - & - & - \\
\hline Unsatisfactory & - & - & - & - \\
\hline
\end{tabular}

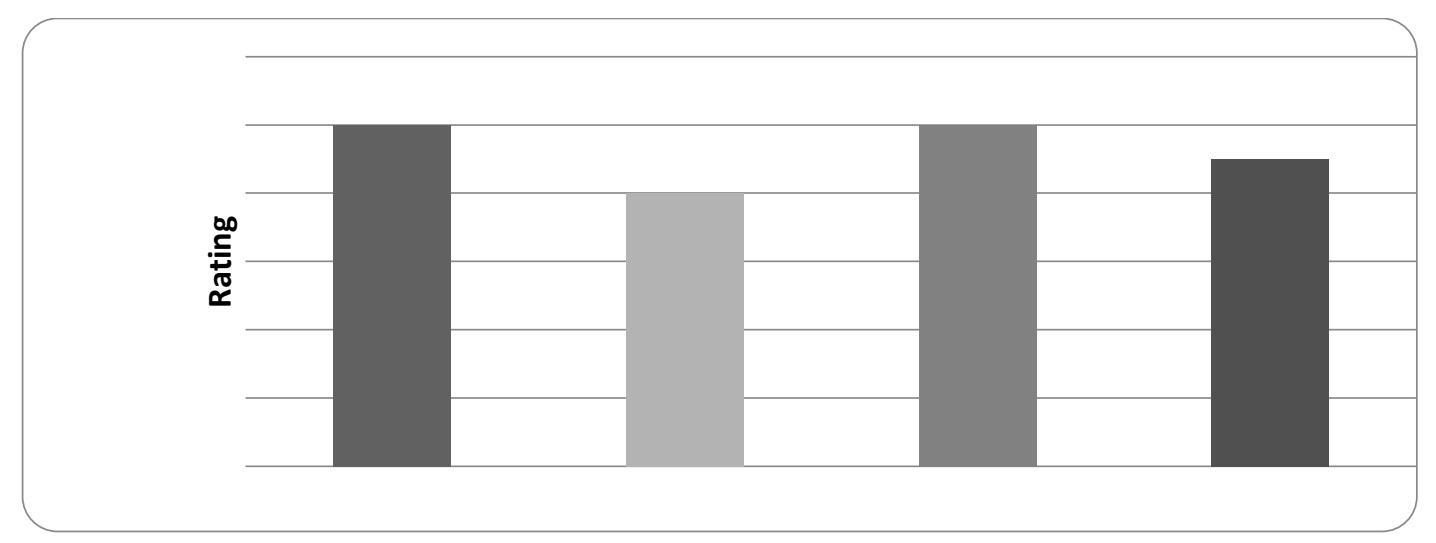

Figure 7: Graph representing the sensory chart

\section{Conclusions}

The ragi (finger millet) chips are prepared by using both oil frying and oven baking. The sample prepared using oil frying gives more crispiness than oven baking method. The sample is assured to withstand its shelf life more than a year due to its complete removal of moisture. On comparison the oil frying is appreciable one than baking. Addition of garlic and ginger gives 
tastier product. High dietary fibre and phenolic content makes Finger millet chips very beneficial for diabetic patients. Apart from this it also has low glycemic index (GI) that make it an ideal snack to prevent late night thirst and helps to maintain blood sugar at constant ratio.

\section{References}

[1] Finger millet facts and statistics from blackherbal.com

[2] Millets grains: Nutritional quality, processing and potential health benefits. Author: Ahmed S.M saleh,Qing Zhang,Jing chen,Qun shen, published in 8,April, 2013.

[3] A. Gull, R. Jan, G.A. Nayik, K. Prasad, P. Kumar, Significance of Finger millet in nutrition, health and value-added products: a review J.Environ.sci.comput.sci.Eng. Technol., 3(3) (2014),pp,1601-1608.

*Corresponding author.

E-mail address: Sinthiya1602@gmail.com/Vaishnavamani98@gmail.com 